Article

\title{
Isolation, Identification and Antimicrobial Activities of Two Secondary Metabolites of Talaromyces verruculosus
}

\author{
Fang Miao ${ }^{1}$, Rui Yang ${ }^{2}$, Dong-Dong Chen ${ }^{2}$, Ying Wang ${ }^{1}$, Bao-Fu Qin ${ }^{1}$, Xin-Juan Yang ${ }^{1,2, *}$ \\ and Le Zhou ${ }^{2, *}$
}

1 College of Life Science, Northwest A\&F University, Yangling, Shaanxi 712100, China

2 College of Science, Northwest A\&F University, Yangling, Shaanxi 712100, China

* Authors to whom correspondence should be addressed; E-Mails: yxj@nwsuaf.edu.cn (X.-J.Y.); zhoulechem@nwsuaf.edu.cn (L.Z.); Tel./Fax: +86-29-8709-2226.

Received: 16 October 2012; in revised form: 21 November 2012 / Accepted: 23 November 2012 / Published: 28 November 2012

\begin{abstract}
From the ethyl acetate extract of the culture broth of Talaromyces verruculosus, a rhizosphere fungus of Stellera chamaejasme L., (-)-8-hydroxy-3-(4-hydroxypentyl)-3,4dihydroisocoumarin (1) and (E)-3-(2,5-dioxo-3-(propan-2-ylidene)pyrrolidin-1-yl)acrylic acid (2) were isolated and evaluated for their antimicrobial activities. Their structures were elucidated by UV, IR, MS, ${ }^{1} \mathrm{H}-\mathrm{NMR},{ }^{13} \mathrm{C}-\mathrm{NMR}$ and $2 \mathrm{D}$ NMR spectra. Compound $\mathbf{1}$ exhibited the significant activities in vitro against two strains of bacteria and four strains of fungi. Compound 2 gave slight activities on the fungi at $100 \mu \mathrm{g} \mathrm{mL}^{-1}$, but no activities on the bacteria. Compound $\mathbf{1}$ should be considered as a new lead or model compound to develop new isocoumarin antimicrobial agents.
\end{abstract}

Keywords: antimicrobial activity; isocoumarin; Talaromyces verruculosus; rhizosphere microorganism; Stellera chamaejasme L.

\section{Introduction}

The term rhizosphere microorganism refers to a bacterial or a fungal microorganism that colonizes the region of the soil immediately adjacent (within $1 \mathrm{~mm}$ ) to plant roots [1]. Rhizosphere microorganisms are different from those living in the nonrhizosphere surrounding soil, both in gross numbers of cells and the variety of strains. The rhizosphere microbial communities influence growth, resistance to disease or even death of the plant host depending on the degree of parasitism and 
pathogenicity $[1,2]$. The rhizosphere communities of plant species differ from each other $[3,4]$. The diversity of microbial strains in the rhizosphere is influenced by different plant species $[5,6]$ and environmental factors affecting plant growth [7]. Recently, rhizosphere microorganisms have been recognized as an important source of a variety of structurally novel active secondary metabolites. As a representative example, Gunatilaka et al. have isolated 18 new natural products and 23 known compounds from nine strains of Sonoran desert plant-associated rhizosphere fungi [8-15]. However, compared with those of endophytes, the secondary metabolites of rhizosphere microorganisms had not received much attention.

Stellera chamaejasme L. (Thymelaeceae) is a perennial herb and widely distributed in North China. Its roots have been used in Chinese traditional herb medicine as an external medicament. Our previous study resulted in the isolation of a fungal strain from the rhizosphere soil of Stellera chamaejasme L. identified as Penicillium verruculosum YL-52, which was revised as Talaromyces verruculosus by Samson et al. in 2011 [16]. Meanwhile, the ethyl acetate extract of the culture broth of the fungus exhibited obvious antifungal activities against 11 strains of plant pathogens and antibacterial activities against four bacterial strains [17]. The aim of the present study was to determine the chemical constituents of the ethyl acetate extract and its active compounds. Herein, we reported the isolation and identification of two compounds from the ethyl acetate extract and their antimicrobial activities.

\section{Results and Discussion}

\subsection{Isolation and Structural Identification}

Repeated silica gel column chromatography of the ethyl acetate extract of the culture broth of the fungus YL-52, followed by purification of Sephadex LH-20 column chromatography, revealed two compounds 1 and 2 (Figure 1).

Figure 1. The structures of compounds $\mathbf{1}$ and $\mathbf{2}$.
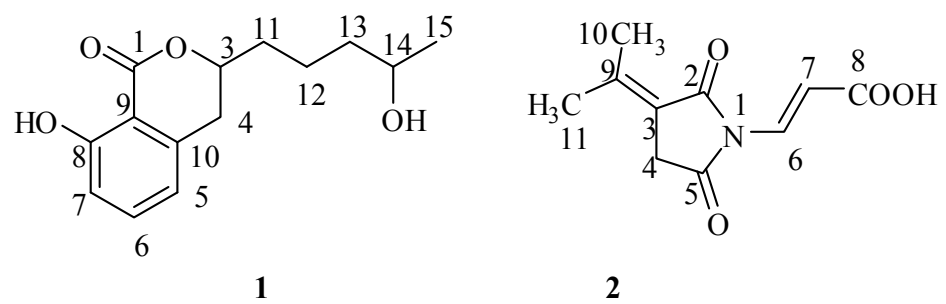

Compound 1, isolated as white needle crystals, showed a quasi-molecular ion peak at $\mathrm{m} / \mathrm{z} 251.1279$ $[\mathrm{M}+\mathrm{H}]^{+}$in HRMS corresponding to the molecular formula $\mathrm{C}_{14} \mathrm{H}_{18} \mathrm{O}_{4}$. The molecular formula indicated six degrees of unsaturation within the molecule. IR spectrum revealed the presence of $\mathrm{OH}$ groups (3419, 1239, $\left.1120 \mathrm{~cm}^{-1}\right), \mathrm{C}=\mathrm{O}$ group $\left(1657 \mathrm{~cm}^{-1}\right)$ and benzene ring $\left(3080,1617,1584 \mathrm{~cm}^{-1}\right)$. UV absorption maxima at $\lambda_{\max } 246 \mathrm{~nm}(\log \varepsilon 3.75)$ and $314 \mathrm{~nm}(\log \varepsilon$ 3.56) disclosed the presence of a conjugated system. The ${ }^{1} \mathrm{H}-\mathrm{NMR}$ displayed the presence of three aromatic hydrogen atoms $\left(\delta_{\mathrm{H}} 7.44\right.$, $6.92,6.72)$. Based on the multiplicity and coupling constant of each peak, the three hydrogen atoms above were considered as a system of three vicinal aromatic protons. In addition, the ${ }^{1} \mathrm{H}-\mathrm{NMR}$ spectrum showed the presence of one methyl group $\left(\delta_{\mathrm{H}} 1.25, d\right)$, two oxygenated methenyl groups 
$\left(\delta_{\mathrm{H}} 4.59-4.65,3.88\right)$ and one phenolic hydroxyl group $\left(\delta_{\mathrm{H}} 11.04\right)$. In the ${ }^{13} \mathrm{C}-\mathrm{NMR}$ spectrum, fourteen carbon atom signals were observed. The DEPT spectrum showed one signal for one carbonyl carbon atom, six signals for $\mathrm{sp}^{2}$-hybridized carbon atoms $(3 \times \mathrm{C}$ and $3 \times \mathrm{CH})$, and seven signals for $\mathrm{sp}^{3}$-hybridized carbon atoms $\left(1 \times \mathrm{CH}_{3}, 2 \times \mathrm{OCH}\right.$ and $\left.4 \times \mathrm{CH}_{2}\right)$. The signals at $\delta_{\mathrm{C}} 162.0$ suggested the presence of one oxygenated aromatic carbon atom.

The UV and IR data were good agreement with those published for 3-(2-hydroxypropyl)-8-hydroxy3,4-dihydroisocoumarin isolated from the Chinese mangrove associate Catunaregam spinosa [18], suggesting that compound $\mathbf{1}$ contained an 8-hydroxy-3,4-dihydroisocoumarin moiety. The ${ }^{13} \mathrm{C}-\mathrm{NMR}$ spectrum was very similar to that of 3-(2-hydroxypropyl)-8-hydroxy-3,4-dihydroisocoumarin, except for the presence of two additional methylenes. Moreover, the location of the hydroxyl group at C-14 was determined by the HMBC correlations between $\mathrm{H}-15\left(\delta_{\mathrm{H}} 1.25\right)$ and $\mathrm{C}-14\left(\delta_{\mathrm{C}} 67.8\right)$ and between the proton of $14-\mathrm{OH}$ and $\mathrm{C}-14$, as well as the coupling relationship between $\mathrm{H}-15\left(\delta_{\mathrm{H}} 1.25\right)$ and $\mathrm{H}-14$ $\left(\delta_{\mathrm{C}} 3.88\right)$ in ${ }^{1} \mathrm{H}-\mathrm{NMR}$ spectrum. The assignment of all proton signals in ${ }^{1} \mathrm{H}-\mathrm{NMR}$ spectrum was carried out by HSQC and HMBC correlations. Based on the facts above, $\mathbf{1}$ was established as 3-(4-hydroxypentyl)-8-hydroxy-3,4-dihydroisocoumarin. The optical rotation $\left([\alpha]_{\mathrm{D}}{ }^{25}-40.4\right.$ (c 0.19 , acetone)) showed that 1 was an optically pure chiral compound, but the configurations at C-3 and C-14 remained unsolved because the crystal of 1 was too fragile for an X-ray crystallographic determination. A similar case was observed for 3-(2-hydroxypropyl)-8-hydroxy-3,4-dihydroisocoumarin [17].

Compound 2 was obtained as a white powder, and established as (E)-3-(2,5-dioxo-3-(propan-2ylidene)pyrrolidin-1-yl) acrylic acid by X-ray crystallographic analysis in our previous study [18]. Herein, we further reported its other previously unpublished spectroscopic data. Compound 2 possessed a molecular formula of $\mathrm{C}_{10} \mathrm{H}_{11} \mathrm{NO}_{4}$, as deduced from its quasi-molecular ion peak at $\mathrm{m} / \mathrm{z}$ 210.0762 $[\mathrm{M}+\mathrm{H}]^{+}$in HR-ESI-MS. The molecular formula indicated six degrees of unsaturation. The IR spectrum revealed the presence of an $\mathrm{OH}$ group $\left(3431,1234 \mathrm{~cm}^{-1}\right), \mathrm{C}=\mathrm{O}$ groups $\left(1714,1628 \mathrm{~cm}^{-1}\right)$ and $\mathrm{CH}_{3}$ groups $\left(2924,1359 \mathrm{~cm}^{-1}\right)$; The UV disclosed absorption maxima at $\lambda_{\max } 262 \mathrm{~nm}(\log \varepsilon 4.01)$, due to the presence of a conjugated system; The ${ }^{1} \mathrm{H}-\mathrm{NMR}$ spectrum exhibited the presence of two methyl groups at $\delta_{\mathrm{H}} 2.35(3 \mathrm{H}, s)$ and $1.93(3 \mathrm{H}, s)$, two olefinic protons at $\delta 7.78(1 \mathrm{H}, d)$ and $6.91(1 \mathrm{H}, d)$, and one methylene group at $\delta_{\mathrm{H}} 3.35(2 \mathrm{H}, s)$. The above findings were further supported by the DEPT spectrum. The ${ }^{13} \mathrm{C}$-NMR spectrum displayed 10 signals, of which five were assigned to quaternary carbon atoms by DEPT. Based on the large coupling constant of the signals at $\delta_{\mathrm{H}} 7.78(1 \mathrm{H}, d, J=14.8)$ and $6.91(1 \mathrm{H}, d, J=14.8)$, a trans configuration was established for the $\Delta^{6}$-double bond. In the HMBC spectrum, the correlations between $\mathrm{H}-6$ and $\mathrm{C}-2, \mathrm{C}-5, \mathrm{C}-8$ suggested that the $\mathrm{CH}=\mathrm{CHCO}_{2} \mathrm{H}$ group was attached to a nitrogen atom, and the correlations between $\mathrm{H}-10$ and C-3, C-9, C-11 and between H-11 and C-3, C-9, C-10 suggested the occurrence of one propan-2-ylidene moiety at the C-3 position. From the foregoing, it was concluded that compound 2 was (E)-3-(2,5-dioxo-3-(propan-2-ylidene)pyrrolidin$1-y l)$ acrylic acid, in agreement with its X-ray crystallographic analysis result [19].

\subsection{Bioactivity}

The antimicrobial activities of $\mathbf{1}$ and $\mathbf{2}$ were determined against pathogenic bacteria and fungi as listed in Table 1. The results showed that $\mathbf{1}$ had obvious antibacterial activities against Staphylococcus 
aureus and Escherichia coli, with minimum inhibitory concentration (MIC) values of $2.5 \mu \mathrm{g} \mathrm{mL}^{-1}$ and $5.0 \mu \mathrm{g} \mathrm{mL}^{-1}$, respectively, but $\mathbf{1}$ was less active than the standard drug ceftriaxone sodium (a broad-spectrum antibiotic) with an MIC value of $0.625 \mu \mathrm{g} \mathrm{mL}{ }^{-1}$. For plant pathogenic fungi, 1 disclosed significant growth inhibitions of $92.6 \pm 2.1 \%, 97.3 \pm 3.3 \%, 87.2 \pm 2.8 \%$ and $94.9 \pm 1.9 \%$ at $50 \mu \mathrm{g} \mathrm{mL}^{-1}$ against Alternaria solani, Valsa mali, Curvularia lunata and Botryosphaeria berengeriana, respectively. Under the same conditions, the growth inhibitions of thiabendazole, a broad-spectrum antifungal drug, were $54.7 \pm 2.6 \%, 100 \pm 0.0 \%, 51.5 \pm 4.1$, compound 2 was inactive for both the tested bacteria and fungi, although it showed slight antifung\% and $92.8 \pm 3.7 \%$. Obviously, 1 had higher activities than thiabendazole against phytopathogenic fungi. Under the same conditions al activities at a concentration of $100 \mu \mathrm{g} \mathrm{mL}^{-1}$.

Table 1. In vitro antimicrobial activities of $\mathbf{1}$ and $\mathbf{2}\left(50 \mu \mathrm{g} \mathrm{mL} L^{-1}\right)$.

\begin{tabular}{|c|c|c|c|c|c|c|}
\hline \multirow{2}{*}{ Compound } & \multicolumn{4}{|c|}{ Growth inhibition $(\%$, mean \pm SD) } & \multicolumn{2}{|c|}{$\mathrm{MIC}\left(\mu \mathrm{g} \mathrm{mL} \mathrm{L}^{-1}\right)$} \\
\hline & A. solani & V. mali & C. lunata & B. berengeriana & S. aureus & E. coli \\
\hline 1 & $92.6 \pm 2.1$ & $97.3 \pm 3.3$ & $87.2 \pm 2.8$ & $94.9 \pm 3.9$ & 2.5 & 5.0 \\
\hline 2 & $\mathrm{~N}^{\mathrm{a}}(16.3 \pm 5.4)^{\mathrm{b}}$ & $\mathrm{N}(21.3 \pm 4.6)$ & $\mathrm{N}(25.6 \pm 5.4)$ & $\mathrm{N}(19.7 \pm 3.8)$ & $>100$ & $>100$ \\
\hline Thiabendazole & $54.7 \pm 2.6$ & $100 \pm 0.0$ & $51.5 \pm 4.1$ & $92.8 \pm 3.7$ & - & - \\
\hline $\begin{array}{c}\text { Ceftriaxone } \\
\text { sodium } \\
\end{array}$ & - & - & - & - & 0.625 & 0.625 \\
\hline
\end{tabular}

${ }^{a}$ : N: No inhibition of growth was observed at $50 \mu \mathrm{g} \mathrm{mL}{ }^{-1} ;{ }^{b}$ : The numbers in parentheses were growth

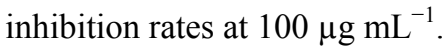

\section{Experimental}

\subsection{General}

Optical rotations: Horiba SEPA-300 digital polarimeter. IR spectra: Nexus FT-IR 400 spectrometer; with $\mathrm{KBr}$ pellets; in $\mathrm{cm}^{-1}$. UV spectra: SP-2100 UV/VIS spectrometer; $\lambda_{\max }(\log \varepsilon)$ in $\mathrm{nm}$. NMR spectra were recorded on Bruker AV-400 spectrometers with TMS as an internal standard. MS spectra were recorded with a VG Autospec-3000 spectrometer. HR-ESI-MS were recorded with an API QSTAR Pulsar 1 spectrometer; in $\mathrm{m} / \mathrm{z}$. Column chromatography was carried out on silica gel (200-300 mesh, Qingdao Marine Chemical Inc., Qingdao, China) and Sephadex LH-20 (Pharmacia, New Jersey, NJ, USA). Fractions were monitored by TLC and spots were visualized by heating silica gel plates sprayed with $10 \% \mathrm{H}_{2} \mathrm{SO}_{4}$ in ethanol.

\subsection{Plant and Fungal Strain Materials}

The fungal strain was isolated in the rhizosphere soil of Stellera chamaejasme L. collected in the Qinling Mountains of Taibai town in Shaanxi Province, China, in August 2007 and deposited in the Laboratory of Natural Product Research, Northwest A\&F University, Shaanxi Province, China (culture collection number YL-52). The fungus was identified as Penicillium verruculosum YL-52 (the revised name: Talaromyces verruculosus) by the streak plate method, morphological characteristics, sequence analysis of ITS and comparison analysis with GenBankB data [16]. 


\subsection{Fermentation}

Cultures of YL-52 maintained on potato-dextrose-agar (PDA) medium slants were subcultured in Petri dishes prior to testing. Two fungal cakes $(d=13 \mathrm{~mm})$ were added to a $250 \mathrm{~mL}$ conical flask containing $100 \mathrm{~mL}$ potato-dextrose broth (PDB), and cultured for $9 \mathrm{~d}$ at $25{ }^{\circ} \mathrm{C}$ with a $150 \mathrm{r} / \mathrm{min}$ frequency in a rocking bed. A $60 \mathrm{~L}$ culture broth was obtained from 600 fermentation flasks.

\subsection{Extraction and Isolation}

The culture broth $(60 \mathrm{~L})$ was extracted with ethyl acetate $(50 \mathrm{~L} \times 3)$. The combined ethyl acetate solution was concentrated under vacuum to yield $12.8 \mathrm{~g}$ of crude extract. Ten grams of the extract were subjected to column chromatography over silica gel using $\mathrm{CHCl}_{3}-\mathrm{CH}_{3} \mathrm{OH}$ (stepwise gradient: 100:1, $50: 1,25: 1,10: 1,5: 1,1: 1,0: 1, \mathrm{v} / \mathrm{v})$ to furnish the corresponding fractions A-1 (0.8 g), A-2 (3.80 g), A-3 (1.44 g), A-4 (1.21 g), A-5 (0.32 g), A-6 (0.30 g) and A-7 (1.95 g). Fractions A-2 and A-3 were combined and subjected to column chromatography over silica gel using petroleum ether-EtOAc (stepwise gradient: $20: 1,15: 1,10: 1,5: 1,1: 1,0: 1$; petroleum ether: b.p. $60-90{ }^{\circ} \mathrm{C}$ ) to obtain corresponding subfractions B-1 (0.57 g), B-2 (0.76 g), B-3 (0.97 g), B-4 (0.86 g), B-5 (0.94 g) and B-6 (0.90 g). Subfractions B-3 and B-4 were combined, and subjected to column chromatography on $\mathrm{SiO}_{2}$ with petroleum ether-acetone (stepwise gradient: 10:1, 8:1, 5:1, 2:1, 1:1, 0:1). The petroleum ether-acetone (5:1) eluate was sequentially subjected to preparative silica gel TLC using petroleum ether-acetone (2:1) and Sephadex LH-20 column chromatography with methanol. Compound 1 (16 mg) was obtained as colorless needle-like crystals (petroleum ether-EtOAc, 1:1). Fractions A-5 and A-6 were combined and repeatedly subjected to column chromatography over silica gel using petroleum ether-acetone mixture (stepwise gradient: 5:1, 2:1, 1:1, 0.5:1). The petroleum ether-acetone (0.5:1) eluate was purified by preparative silica gel TLC $\left(\mathrm{CHCl}_{3}-\mathrm{CH}_{3} \mathrm{OH}, 1: 1\right)$ and Sephadex LH-20 column chromatography using methanol to provide $\mathbf{2}(14 \mathrm{mg})$ as a white powder.

3-(4-Hydroxypentyl)-8-hydroxy-3,4-dihydroisocoumarin (1). White needle-like crystals (petroleum ether-ethyl acetate), $R_{\mathrm{f}}=0.35$ (petroleum ether-acetone, 2:1), $0.56\left(\mathrm{CHCl}_{3}-\mathrm{CH}_{3} \mathrm{OH}, 8: 1\right)$, m.p. $80-81$ ${ }^{\circ} \mathrm{C},[\alpha]_{\mathrm{D}}{ }^{25}-40.4$ (c 0.19, acetone); UV (95\% EtOH): $\lambda_{\max }(\log \varepsilon)=212$ (4.30), 246 (3.75), 314 (3.56) $\mathrm{nm}$; IR $(\mathrm{KBr}): v_{\max }=3419,3080,2946,1657,1617,1584,1462,1239,1120 \mathrm{~cm}^{-1} ;{ }^{13} \mathrm{C}-\mathrm{NMR}(100$ $\left.\mathrm{MHz}, \mathrm{CDCl}_{3}\right) \delta$ ppm: 169.8 (C-1), 162.0 (C-8), 139.3 (C-10), 136.1 (C-6), 117.9 (C-5), 116.1 (C-7), 108.3 (C-9), 79.6 (C-3), 67.8 (C-14), 38.7 (C-13), 34.7 (C-11), 32.8 (C-4), 23.6 (C-15), 21.1 (C-12); ${ }^{1} \mathrm{H}-\mathrm{NMR}\left(400 \mathrm{MHz}, \mathrm{CDCl}_{3}\right) \delta \mathrm{ppm}: 11.04(1 \mathrm{H}, s, 8-\mathrm{OH}), 7.44(1 \mathrm{H}, t$-like, $J=8.0 \mathrm{~Hz}, \mathrm{H}-6), 6.92(1 \mathrm{H}$, $d, J=8.4 \mathrm{~Hz}, \mathrm{H}-7), 6.72(1 \mathrm{H}, d, J=7.6 \mathrm{~Hz}, \mathrm{H}-5), 4.59-4.65(1 \mathrm{H}, m, \mathrm{H}-3), 2.96-2.99$ (2H, $m, \mathrm{H}-4)$, 1.89-2.00 (1H, $m, \mathrm{H}-11 \mathrm{a}), 1.77-1.85(1 \mathrm{H}, m, \mathrm{H}-11 \mathrm{~b}), 1.60-1.77$ (2H, $m, \mathrm{H}-12), 1.50-1.56(2 \mathrm{H}, m$, H-13), $3.88(1 \mathrm{H}$, hepta, $J=6.4,11.6,17.6 \mathrm{~Hz}, \mathrm{H}-14), 1.25(3 \mathrm{H}, d, J=6.4 \mathrm{~Hz}, \mathrm{H}-15), 1.69(1 \mathrm{H}, s$, 14-OH); Main HMBC correlations: $\delta_{\mathrm{H}} 2.96-2.99(\mathrm{H}-4) / \delta_{\mathrm{C}} 79.6(\mathrm{C}-3), 117.9(\mathrm{C}-5), 108.3(\mathrm{C}-9), 139.3$ $(\mathrm{C}-10) ; \delta_{\mathrm{H}} 6.72(\mathrm{H}-5) / \delta_{\mathrm{C}} 32.8(\mathrm{C}-4), 108.3(\mathrm{C}-9) ; \delta_{\mathrm{H}} 7.44(\mathrm{H}-6) / \delta_{\mathrm{C}} 116.1(\mathrm{C}-7), 139.3(\mathrm{C}-10) ; \delta_{\mathrm{H}}$ $6.92(\mathrm{H}-7) / \delta_{\mathrm{C}} 117.9(\mathrm{C}-5), 108.3(\mathrm{C}-9) ; \delta_{\mathrm{H}} 1.89-2.00(\mathrm{H}-11 \mathrm{a}), 1.77-1.85(\mathrm{H}-11 \mathrm{~b}) / \delta_{\mathrm{C}} 79.6(\mathrm{C}-3)$; $\delta_{\mathrm{H}} 1.50-1.56(\mathrm{H}-13) / \delta_{\mathrm{C}} 23.6(\mathrm{C}-15) ; \delta_{\mathrm{H}} 1.25(\mathrm{H}-15) / 67.8(\mathrm{C}-14), 38.7(\mathrm{C}-13) ; \delta_{\mathrm{H}} 1.69(14-\mathrm{OH}) /$ $67.8(\mathrm{C}-14), 23.6(\mathrm{C}-15) ;(+)$-ESI MS $m / z=251.0[\mathrm{M}+\mathrm{H}]^{+} ;(+)$-ESI HR MS $m / z=251.1279[\mathrm{M}+\mathrm{H}]^{+}$ (calcd. for $\mathrm{C}_{14} \mathrm{H}_{19} \mathrm{O}_{4}, 251.1283$ ). 
(E)-3-(2,5-Dioxo-3-(propan-2-ylidene)pyrrolidin-1-yl)acrylic acid (2). White powders, $R_{\mathrm{f}}=0.54$ (chloroform-methanol-EtOAc, 2:3:3), 0.76 (chloroform-methanol, 1:1), m.p. 194-195 ${ }^{\circ} \mathrm{C}$; UV $(95 \% \mathrm{EtOH}): \lambda_{\max }(\log \varepsilon)=262(4.01) \mathrm{nm}$; IR $(\mathrm{KBr}): v_{\max }=3431,2924,1714,1628,1359,1234 \mathrm{~cm}^{-1}$; ${ }^{13} \mathrm{C}-\mathrm{NMR}\left(100 \mathrm{MHz}, \mathrm{CDCl}_{3}\right.$ ) $\delta$ ppm: 173.9 (C-8), 170.9 (C-5), 168.3 (C-2), 154.1 (C-9), 133.2 (C-6), 119.3 (C-3), 110.9 (C-7), 48.6 (C-4), 24.4 (C-11), 21.0 (C-10); ${ }^{1} \mathrm{H}-\mathrm{NMR}$ (400 MHz, CDCl $\left.{ }_{3}\right) \delta$ ppm: $7.78(1 \mathrm{H}, d, J=14.8 \mathrm{~Hz}, \mathrm{H}-6), 6.91(1 \mathrm{H}, d, J=14.8 \mathrm{~Hz}, \mathrm{H}-7), 3.35(2 \mathrm{H}, s, \mathrm{H}-4), 2.35$ (3H, $s, \mathrm{H}-10)$, $1.93(3 \mathrm{H}, s, \mathrm{H}-11)$; Main HMBC correlations: $\delta_{\mathrm{H}} 7.78(\mathrm{H}-6) / \delta_{\mathrm{C}} 173.9(\mathrm{C}-8), 170.9(\mathrm{C}-5), 168.3(\mathrm{C}-2)$; $\delta_{\mathrm{H}} 6.91(\mathrm{H}-7) / \delta_{\mathrm{C}} 133.2(\mathrm{C}-6) ; \delta_{\mathrm{H}} 2.35(\mathrm{H}-10) / \delta_{\mathrm{C}} 154.1(\mathrm{C}-9), 119.3(\mathrm{C}-3), 24.4(\mathrm{C}-11) ; \delta_{\mathrm{H}} 1.93(\mathrm{H}-11) /$ $\delta_{\mathrm{C}} 154.1(\mathrm{C}-9), 119.3(\mathrm{C}-3), 21.0(\mathrm{C}-10) ;(+)$-ESI MS $m / z=209.9[\mathrm{M}+\mathrm{H}]^{+}$; (+)-ESI HR MS $m / z=210.0762[\mathrm{M}+\mathrm{H}]^{+}$(calcd. for $\mathrm{C}_{10} \mathrm{H}_{12} \mathrm{NO}_{4}, 210.0766$ ).

\subsection{Antibacterial Assay}

The antibacterial activity was determined by method reported in the literature [20]. A LB (LuriaBertani) broth $(50 \mathrm{~mL})$ was used for culturing E. coli and $S$. aureus. Half milliliter of the $24 \mathrm{~h}$ cultured fresh broth at $37{ }^{\circ} \mathrm{C}$ was diluted by $50 \mathrm{~mL}$ of the same broth to indicate a $0.5 \mathrm{McF}$ arland $(\mathrm{McF}$ ) turbidity (ca. $1.5 \times 10^{8}$ colony forming unit). A tested compound was dissolved in dimethylsulfoxide (DMSO) to provide a sample solution of $0.8 \mathrm{mg} \mathrm{mL}^{-1}$, and then double-fold serial dilutions $\left(0.625-160 \mu \mathrm{g} \mathrm{mL}^{-1}\right)$ were made by adding Mueller-Hinton broth. Each sample solution $(100 \mu \mathrm{L})$ was completely mixed with the bacterial suspension $(100 \mu \mathrm{L})$ in a well of 96 -well polystyrene plate. After incubation of the plates for $24 \mathrm{~h}$ at $37^{\circ} \mathrm{C}$, the absorbance of each well was measured at $630 \mathrm{~nm}$ with a microtiter plate reader (BioRad). According to the same, were prepared and used as positive control. Five percent DMSO in the same broth served method as the tested compounds, the double-fold serial solutions of ceftriaxone sodium $\left(0.156-2.50 \mu \mathrm{g} \mathrm{mL}^{-1}\right)$, a broad spectrum antibiotics as negative control. All experiments were performed in triplicate. The minimal inhibitory concentration (MIC, $\mu \mathrm{g} \mathrm{mL}{ }^{-1}$ ) was defined as the concentration of a compound required to reduce the absorbance to less than $50 \%$ of that of the negative control.

\subsection{Antifungal Assay}

The antifungal activity in vitro was assayed by the growth rate method [21] with slight modifications. The tested pathogenic fungi were Alternaria solani, Valsa mali, Curvularia lunata and Botryosphaeria berengeriana, provided by the Institute of Pesticides, Northwest A\&F University. Cultures of the test fungi maintained on potato-dextrose-agar (PDA) medium slants were subcultured in Petri dishes prior to testing. Sample solution $\left(1 \mathrm{mg} \mathrm{mL}^{-1}\right)$ in acetone was completely mixed with the autoclaved PDA medium to provide the medium containing $50 \mu \mathrm{g} \mathrm{mL}^{-1}$ of sample, and poured into Petri dishes. Five percent acetone in PDA medium served as negative control. PDA medium containing 50 (or 100) $\mu \mathrm{g} \mathrm{mL}^{-1}$ of thiabendazole, a broad-spectrum antifungal drug, was used as positive control. When the medium in the plates was partially solidified, a 5-mm thick and $4 \mathrm{~mm}$ diameter disc of fungus cut from earlier subcultured Petri dishes was placed at the centre of the semi-solid medium. The treated and control dishes were kept in an incubator at $26( \pm 2){ }^{\circ} \mathrm{C}$ for $72 \mathrm{~h}$. The diameters (in mm) of inhibition zones were measured in three different directions. Growth inhibition rates were calculated according to the following formula and expressed as means $\pm \mathrm{SD}$ : 


$$
\% \text { Growth inhibition rate }=\left(d_{\mathrm{c}}-d_{\mathrm{s}}\right) /\left(d_{\mathrm{c}}-d_{0}\right) \times 100
$$

where $d_{0}$ : Diameter of the fungus cut, $d_{\mathrm{c}}$ : Diameter of the untreated control fungus, $d_{\mathrm{s}}$ : Diameter of the sample-treated fungus.

\section{Conclusions}

In conclusion, the present study described the isolation, characterization and antimicrobial activities of two secondary metabolites $\mathbf{1}$ and $\mathbf{2}$ of Talaromyces verruculosus isolated in the rhizosphere soil of Stellera chamaejasme L. and reported their UV, IR, MS, 1D and 2D NMR spectroscopic data for the first time. Compound 1 showed significant antimicrobial activities against four strains of fungi (A. solani, V. mali, C. lunata, B. berengeriana) at $50 \mu \mathrm{g} \mathrm{mL}^{-1}$ and two strains of bacteria (S. aureus and $E$. coli) with MIC values of $2.5 \mu \mathrm{g} \mathrm{mL}^{-1}$ and $5.0 \mu \mathrm{g} \mathrm{mL}^{-1}$, respectively. Compound 2 was slightly active against the fungi at $100 \mu \mathrm{g} \mathrm{mL}^{-1}$ and its MIC values on the bacteria were more than $100 \mu \mathrm{g} \mathrm{mL}^{-1}$. Compound 1 should be considered as a new lead or model compound to develop new isocoumarin antimicrobial agents.

\section{Acknowledgments}

This project was supported by the National Natural Science Foundation of China (NNSF; No. $31172365,31000865,31101469)$.

\section{References}

1. Whipps, J.M. Microbial interactions and biocontrol in the rhizosphere. J. Exp. Bot. 2001, 52, 487-511.

2. Trejo-Estrada, S.R.; Paszczynski, A.; Crawford, D.L. Antibiotics and enzymes produced by the biocontrol agent Streptomyces violaceusniger YCED-9. J. Ind. Microbiol. Biotech. 1998, 21, 81-90.

3. Smalla, K.; Wachtendorf, U.; Heuer, H.; Liu, W.-T.; Forney, L. Analysis of BIOLOG GN substrate utilization patterns by microbial communities. Appl. Environ. Microbiol. 1998, 64, 1220-1225.

4. Grayston, S.J.; Wang, S.Q.; Campbell, C.D.; Edwards, A.C. Selective influence of plant species on microbial diversity in the rhizosphere. Soil Biol. Biochem. 1998, 30, 369-378.

5. Rovira, A.D. Plant root excretions in relation to the rhizosphere effect I. Plant Soil 1956, 7, 178-194.

6. Berg, G.; Zachow, C.; Lottmann, J.; Gotz, M.; Costa, R.; Smalla, K. Impact of plant species and site on rhizosphere-associated fungi antagonistic to Verticillium dahliae Kleb. Appl. Environ. Microbiol. 2005, 71, 4203-4213.

7. Rovira, A.D. Root excretions in relation to the rhizosphere effect. IV. Influence of plant species, age of plant, light, temperature, and calcium nutrition on exudation. Plant Soil 1959, 11, 53-64.

8. Gunatilaka, A.A.L. Natural products from plant-associated microorganisms: distribution, structural diversity, bioactivity, and implications of their occurrence. J. Nat. Prod. 2006, 69, 509-526.

9. He, J.; Wijeratne, E.M.; Bashyal, B.P.; Zhan, J.; Seliga, C.J.; Liu, M.X.; Pierson, E.E.; Pierson, L.S., III; VanEtten, H.D.; Gunatilaka, A.A. Cytotoxic and other metabolites of Aspergillus inhabiting the rhizosphere of Sonoran desert plants. J. Nat. Prod. 2004, 67, 1985-1991.

10. Kobayashi, A.; Hino, T.; Yata, S.; Itoh, T.J.; Sato, H.; Kawazu, K. Unique spindle poisons, curvularin and its derivatives, isolated from Penicillium species. Agric. Biol. Chem. 1988, 52, 3119-3123. 
11. Zhou, G.X.; Wijeratne, E.M.; Bigelow, D.; Pierson, L.S., III; VanEtten, H.D.; Gunatilaka, A.A. Aspochalasins I, J, and K: Three new cytotoxic cytochalasans of Aspergillus flavipes from the rhizosphere of Ericameria laricifolia of the Sonoran Desert. J. Nat. Prod. 2004, 67, 328-332.

12. Wijeratne, E.M.; Turbyville, T.J.; Zhang, Z.; Bigelow, D.; Pierson, L.S., III; VanEtten, H.D.; Whitesell, L.; Canfield, L.M.; Gunatilaka, A.A. Cytotoxic constituents of Aspergillus terreus from the rhizosphere of Opuntia versicolor of the sonoran desert. J. Nat. Prod. 2003, 66, 1567-1573.

13. Turbyville, T.J.; Wijeratne, E.M.; Whitesell, L.; Gunatilaka, A.A. The anticancer activity of the fungal metabolite terrecyclic acid $\mathrm{A}$ is associated with modulation of multiple cellular stress response pathways. Mol. Cancer Ther. 2005, 4, 1569-1576.

14. Wijeratne, E.M.; Carbonezi, C.A.; Takahashi, J.A.; Seliga, C.J.; Turbyville, T.J.; Pierson, E.E.; Pierson, L.S., III; VanEtten, H.D.; Whitesell, L.; Bolzani, Vda S.; et al. Isolation, optimization of production and structure-activity relationship studies of monocillin I, the cytotoxic constituent of Paraphaeosphaeria quadriseptata. J. Antibiot. 2004, 57, 541-546.

15. Zhan, J.; Wijeratne, E.M.; Seliga, C.J.; Zhang, J.; Pierson, E.E.; Pierson, L.S., III; VanEtten, H.D.; Gunatilaka, A.A. A new anthraquinone and cytotoxic curvularins of a Penicillium sp. from the rhizosphere of Fallugia paradoxa of the Sonoran desert. J. Antibiot. 2004, 57, 341-344.

16. Samson, R.A.; Yilmaz, N.; Houbraken, J.; Spierenburg, H.; Seifert, K.A.; Peterson, S.W.; Varga, J.; Frisvad, J.C. Phylogeny and nomenclature of the genus Talaromyces and taxa accommodated in Penicillium subgenus Biverticillium. Stud. Mycol. 2011, 70, 159-183.

17. Yang, L.Z.; Zhou, L.; Xu, H.; Qin, B.F. Isolation and identification and antifungal activity of a Penicillium. Acta Agric. Boreali-Occid. Sin. 2009, 18, 98-102.

18. Gao, G.C.; Qi, S.H.; Zhang, S.; Yin, H.; Xiao, Z.H.; Li, M.Y.; Li, Q.X. Phenolic compounds and iridoids from the stem bark of Chinese mangrove associate Catunaregam spinosa. Pharmazie 2008, 63, 542-544.

19. Miao, F.; Qin, B.F.; Yang, L.Z.; Yang, X.J.; Zhou, L. (E)-3-[2,5-Dioxo-3-(propan-2-ylidene) pyrrolidin-1-yl]acrylic acid. Acta Cryst. 2010, E66, o634.

20. Guz, N.R.; Stermitz, F.R.; Johnson, J.B.; Beeson, T.D.; Willen, S.; Hsiang, J.-F; Lewis, K. Flavonolignan and flavone inhibitors of a Staphylococcus aureus multidrug resistance pump: structure-activity relationships. J. Med. Chem. 2001, 44, 261-268.

21. Zhang, J.W.; Li, S.K.; Wu, W.J. The main chemical composition and in vitro antifungal activity of the essential oils of ocimum basilicum Linn. var. pilosum (Willd.) Benth. Molecules 2009, 14, 273-278.

Sample Availability: Samples of the compounds $\mathbf{1}$ and $\mathbf{2}$ are available from the authors.

(C) 2012 by the authors; licensee MDPI, Basel, Switzerland. This article is an open access article distributed under the terms and conditions of the Creative Commons Attribution license (http://creativecommons.org/licenses/by/3.0/). 